\title{
Local environmental impact from MSW aerobic biological treatment
}

\author{
E. C. Rada \\ Department of Civil and Environmental Engineering, \\ University of Trento, Italy
}

\begin{abstract}
The present work indentifies some aspects of the environmental impact of two aerobic biological treatments (bio-drying and composting) applied to fractions of municipal solid waste (MSW) taking into account the odor release into the atmosphere and its concentration at ground level. Some scenarios are presented for the process air treatment and management: bio-filter and regenerative thermal oxidation treatment (RTO), at different heights of release. A Gaussian dispersion model, AERMOD, was used in order to assess the dispersion and odor emissions into the atmosphere. Data refer to a case-study region where both the biological plants could be constructed. A site of potential location for one of the two plants was studied from the odor impact point of view. The case of bio-filter at ground level resulted as the most critical, depending on the low dispersion of the pollutants. Technical solutions for the optimization of the impact are also proposed in this paper.
\end{abstract}

Keywords: bio-drying, bio-filter, composting, MSW, odor, RTO.

\section{Introduction}

In the sector of municipal solid waste (MSW) aerobic biological treatment, odor is not related to the presence of only one compound. Thus the management of the related problems is not easy. The interest in this problem has become more and more relevant in the recent years because of the construction of these plants near urbanized areas but also because of the greater attention paid to environmental protection and human health [1-6]. However the odor perception is a complex phenomenon with a strong subjective component. 
Odor is a parameter that cannot be physically or chemically measured, because it is a characteristic of a molecule. The odor concentration is measured in $\mathrm{OU} / \mathrm{m}^{3}$ (odor units per cubic meter). Its perception threshold is defined as the condition of the sample dilution that leads to the perception of smell with a probability of $50 \%$ and is $1 \mathrm{OU} / \mathrm{m}^{3}$.

The aim of this paper is to determine and compare the local environmental impact of two aerobic biological treatments, bio-drying and composting, taking into account the odor emissions. The same location has been analyzed in order to favor a comparative analysis. The third available aerobic process in the MSW sector, bio-stabilization, was not taken into account being an intermediate process compared to the two analyzed.

Even if these processes are well known, a specific European regulation regarding limits for odor concentrations does not exist for each process; there are indications regarding their emissions in national/regional standards or guidelines for biological processes (generally emission limits as $200-500 \mathrm{OU} / \mathrm{m}^{3}$ are proposed) [7, 8].

Moreover, the limit values that can be authorized depend also on the induced concentration in ambient air and take into account the distance (d) of the first receptor or potential receptor from the border of the establishment and the nature of the affected area. An example of the values adopted in Italy, in the Lombardy region, is presented in the table 1 [7]. The German regulation $30 \mathrm{BImSchV}$ regarding the biological treatment plants [8], imposes a distance of $300 \mathrm{~m}$ from the residential areas that must be guaranteed from environmental point of view.

Table 1: $\quad$ Example of odor concentration limits in ambient air [7].

\begin{tabular}{|l|c|c|c|}
\hline & $\mathrm{d}>500 \mathrm{~m}$ & $200<\mathrm{d}<500 \mathrm{~m}$ & $\mathrm{~d}<200 \mathrm{~m}$ \\
\hline & \multicolumn{3}{|c|}{$\mathrm{OU} / \mathrm{m}^{3}$} \\
\hline Residential area & 1 & 2 & 3 \\
\hline Commercial area & 2 & 3 & 4 \\
\hline $\begin{array}{l}\text { Agricultural or industrial } \\
\text { area }\end{array}$ & 3 & 4 & 5 \\
\hline
\end{tabular}

\section{Materials and methods}

As a case study a flat zone in the North of Italy was chosen having about 500,000 inhabitants producing 268,000 $\mathrm{t}_{\mathrm{MSW}} \mathrm{y}^{-1}$ and a MSW selective collection well implemented (about $65 \%$ of efficiency).

According to the analyzed scenario, around one third (35\%) of the produced MSW is planned to be treated in a bio-drying plant, having about $23 \%$ of organic fraction in the input. Bio-drying has no effect on inert in MSW, but affects moisture and volatile solid content. In the case-study, the total input of the plant was assumed as 95,071 $\mathrm{t}_{\mathrm{MSW}} \mathrm{y}^{-1}$. Moreover, about one fifth of the produced MSW, representing the organic and green fractions was planned to be treated in a composting plant. 
The odor dispersions from MSW bio-drying and composting plants were assessed using the Gaussian model AERMOD [9]. Before performing the simulation, it was necessary to know the orography of the area, the meteorological values characterizing the atmospheric boundary layer and the quantity of MSW that will be treated in order to assess the odor flow.

A preprocessor named AERMET [10] that uses available meteorological measurement, representative of the modeling domain, to compute atmospheric boundary layer parameters, was used through AERMOD to estimate profiles of wind, turbulence and temperature.

A Cartesian grid square having the source located in the center was used for the chosen scenarios. For the bio-filter emissions, the considered area had a size $3 \mathrm{~km} \times 3 \mathrm{~km}$, with virtual receptors spaced $20 \mathrm{~m}$, while in the case of point source, a survey area of $4 \mathrm{~km} \times 4 \mathrm{~km}$ and $40 \mathrm{~m}$ mesh was used.

In the model, the emission concentration was hypothesized $250 \mathrm{UO} / \mathrm{m}^{3}$, complying with the Lombardy request (under $300 \mathrm{UO} / \mathrm{m}^{3}$ ).

The composting plant has more areas as emissive sources. In this paper, as hypothesis it was considered that the process air from the reception building and from the biological oxidation areas is treated; the maturation area and the storing area for the final product (after sieving) were supposed to be in an open/covered sector. Also the emission from this area was taken into account in the calculations.

For the bio-drying and composting process air treatments $\left(10 \mathrm{~m}^{3} / \mathrm{kg}_{\mathrm{MSw}}\right.$ and $15 \mathrm{~m}^{3} / \mathrm{kg}_{\mathrm{MSw}}$ respectively) three configurations were analyzed:

- scenario 1: Bio-filter located at ground level (this is the most used option in Italy for mechanical-biological plants); in this case the height of release was assumed as $2 \mathrm{~m}$.

- scenario 2: Bio-filter located on the roof of the plant building; in this case the height of release was assumed as $17 \mathrm{~m}$, as a sum of the height of the building and of the bio-filter thickness.

- scenario 3: Regenerative thermal oxidation (RTO) system (this is an option widely used in Germany) with emission point located at $25 \mathrm{~m}$ (stack height).

\section{Results and discussion}

In this paper the results of the three configurations (varying depending on the solution adopted for the air treatment) are presented in terms of odor concentration induced at ground level in all directions. For a better understanding of the release phenomena, a few isoconcentration maps are presented too.

From fig. 1 and 2 it can be seen that the odor concentration dynamics, for the first scenario (bio-drying and composting with bio-filter located at ground level), is similar in all directions.

The odor concentrations for the bio-drying scenario (fig. 1) drop rapidly in the first $200 \mathrm{~m}$ and then decrease slowly to values close to the unit (within the 
limits for ambient air). In the case of composting scenario this phenomenon is more relevant: even at one $\mathrm{km}$ of distance the values are over $10 \mathrm{OU} / \mathrm{m}^{3}$ (fig. 2). That depends on the presence of multiple sources only partially conveyed.

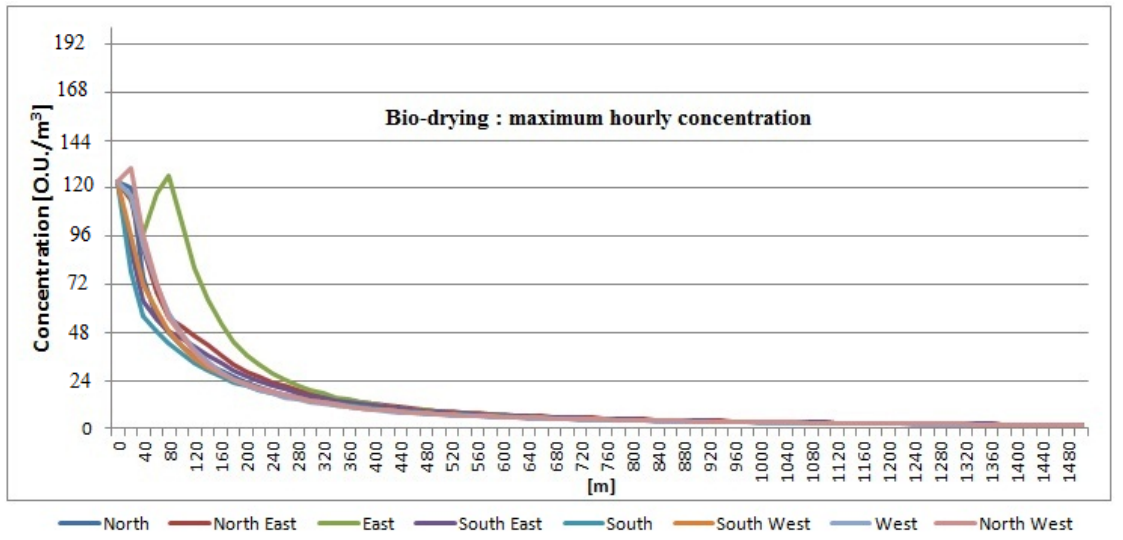

Figure 1: Maximum concentrations of odor along 8 directions in case of biodrying (scenario 1).

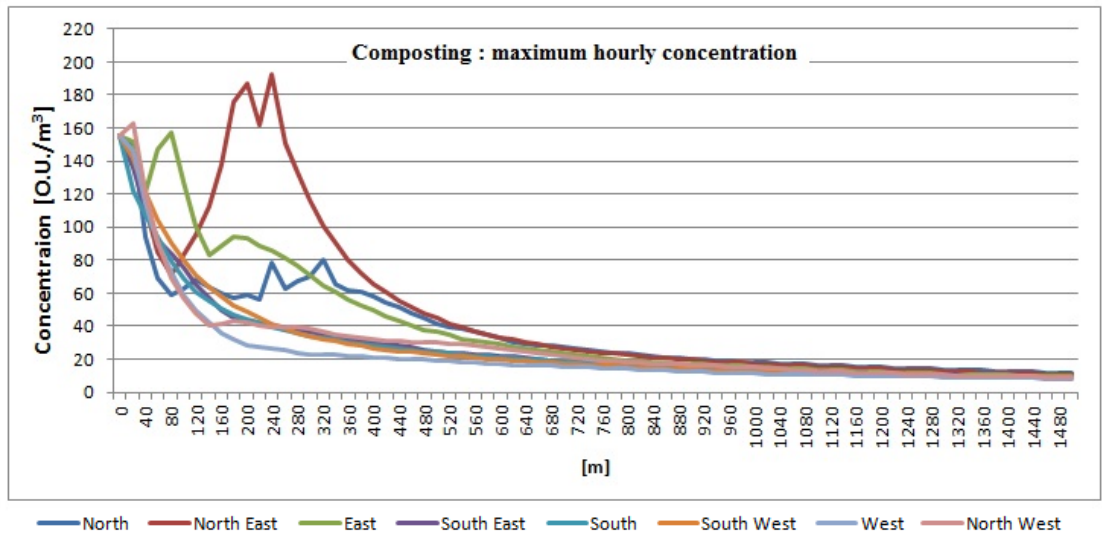

Figure 2: Maximum concentrations of odor along 8 directions in case of composting (scenario 1).

For a better understanding of the phenomenon, a map with isoconcentration lines $\left(\right.$ step $\left.=1 \mathrm{OU} / \mathrm{m}^{3}\right)$ is presented in fig. 3 for the two treatment plants. It must be pointed out that at the borders of the studied area in the case of bio-drying the values are at least equal to 1 . That means that the impact of the plant, with this configuration, is not negligible and does not comply with the Lombardy regulations. In the case of composting the incidence is worst as the odor sources different from bio-filter play a significant role. 
It is clear from the curves of fig. 2 that there are unfavorable directions with impacts that can vary a lot in the areas close to the composting plant. That depends strongly on the meteorological characteristics of the site.
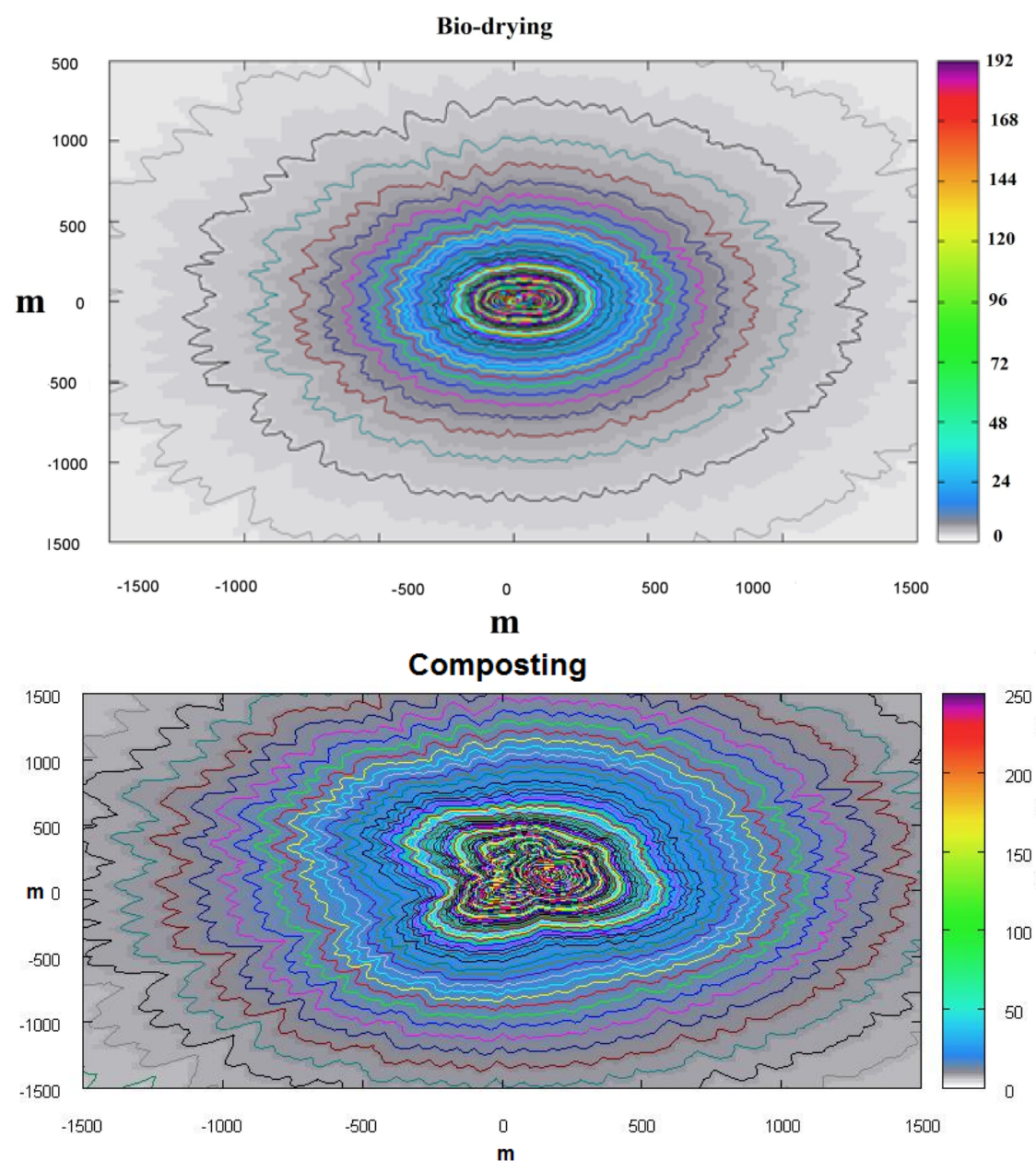

Figure 3: Isoconcentration of maximum hourly values (yearly basis) for biodrying and composting: bio-filter at ground level.

For the second proposed scenario (bio-drying and composting with biofilter located on the roof, with a release height of $17 \mathrm{~m}$ ) the odor concentration dynamics in all directions are presented in fig. 4 and 5.

In case of biofilter at roof level of the bio-drying plant (fig. 4), the impact is much smaller than in the first case, with maximum values, close to the plant, slightly lower than $15 \mathrm{OU} / \mathrm{m}^{3}$ compared to around $130 \mathrm{OU} / \mathrm{m}^{3}$ of the previous configuration. 


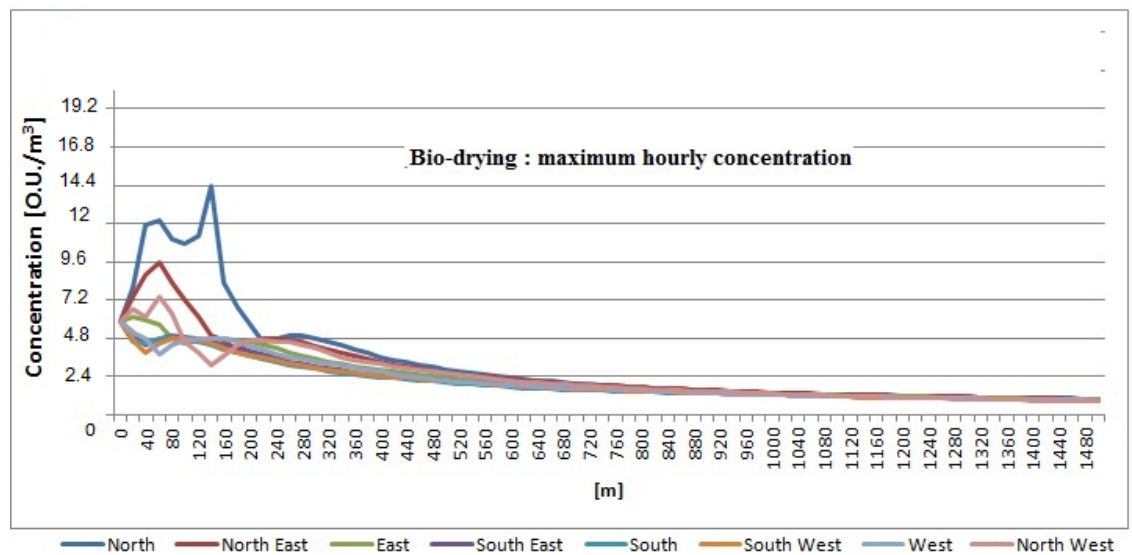

Figure 4: Maximum concentrations of odor along 8 directions in case of biodrying (scenario 2).

In the case of composting (fig. 5), the odor impact for the first and second scenarios are almost the same. One of the reasons is the dominant role of the maturation and storage areas. Indeed, one of the hypothesis of the designs considers not closed these areas. Also in this case the characteristics of local meteorology have an important role in the dilution of the odor compounds released from the plant.

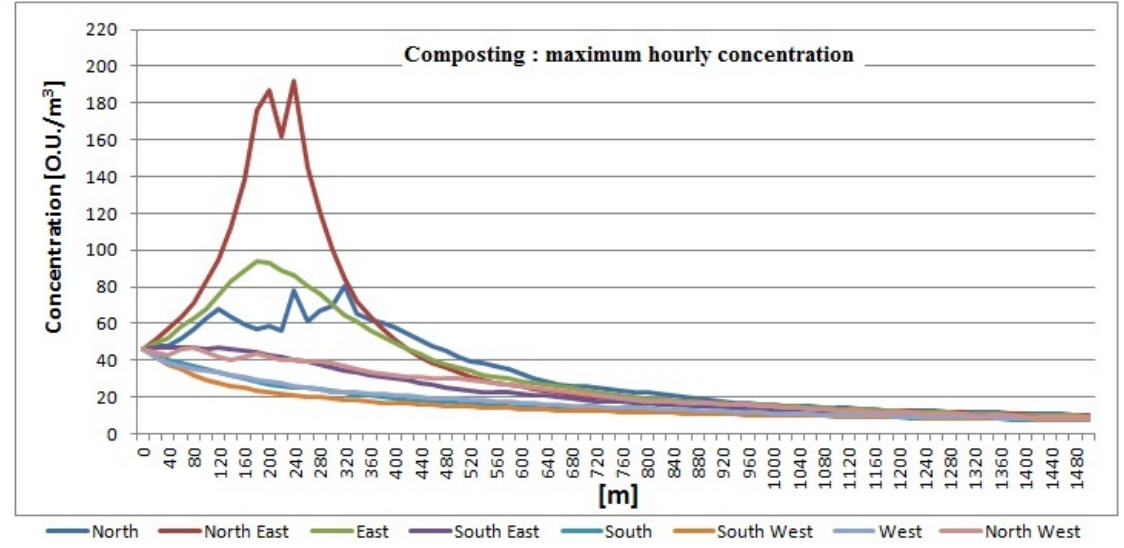

Figure 5: Maximum concentrations of odor along 8 directions in case of composting (scenario 2).

An overview of the phenomenon is given in fig. 6. In spite of a significant decrease of the impact close to the plants, at the borders of the studied area the odor concentration is still not optimized if compared with the Lombardy regulations as odor concentrations are still higher than 1 in both cases. 


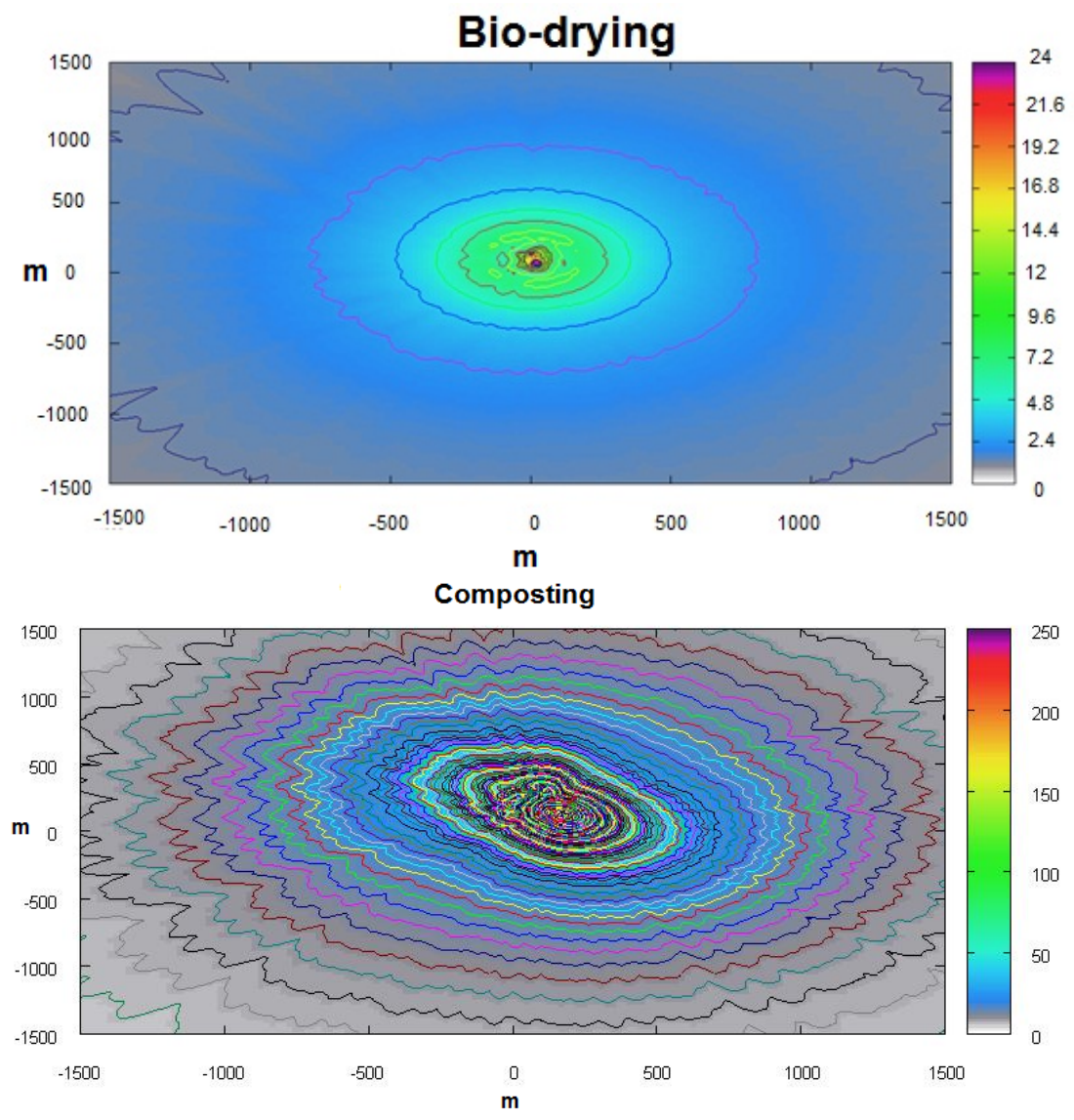

Figure 6: Isoconcentration of maximum hourly values (yearly basis) for biodrying and composting: bio-filter on the roof.

In fig. 7 and 8 the odor concentration dynamics, for the last scenario (biodrying and composting with RTO at $25 \mathrm{~m}$ ), in all directions is presented.

In the case of RTO, it can be observed that for the bio-drying case, the maximum values are one order of magnitude lower than the ones of the second case and three orders of magnitude lower than the ones in the first case, being slightly above $0.1 \mathrm{OU} / \mathrm{m}^{3}$.

The advantage of a stack in case of bio-drying is significant, as this process has no problem of gaseous releases after the closed stage of the biological process. The bio-dried material has a reduced biological activity thanks to the limiting conditions given by the low percentage of moisture $[1,11,12]$. Odor emissions from the product are not relevant if water addition is avoided. 


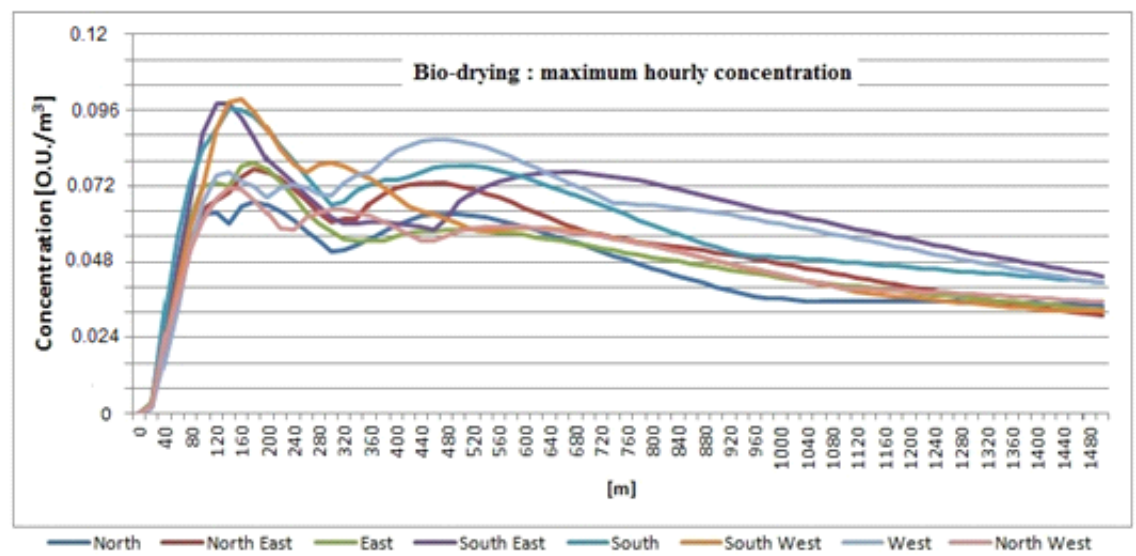

Figure 7: Maximum concentrations of odor along 8 directions in case of biodrying (scenario 3).

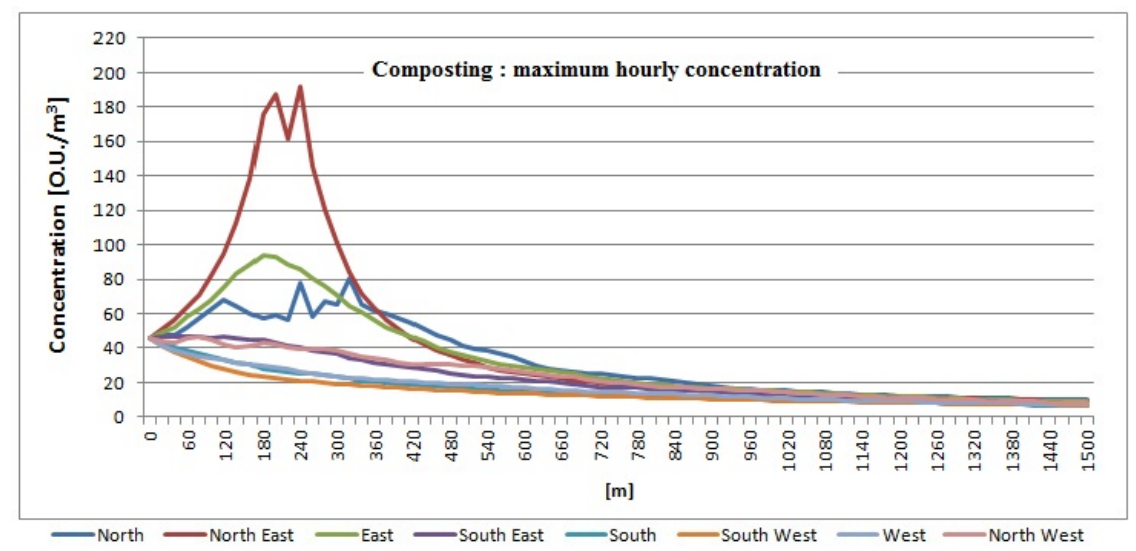

Figure 8: Maximum concentrations of odor along 8 directions in case of composting (scenario 3).

In the case of composting, according to the modeling results, the odor impact did not change significantly if compared with the other two scenarios, mainly because of the maturation and storing areas. It is clear that a real decrease of the impact can be obtained only by the conveyance of the process air from all the areas of the plant. This criterion is not common yet in the sector of composting plant design, possibly because the construction of fully closed plant has costs that could be critical for the composting role, compared to the conventional options.

In fig. 9 the isoconcentration lines for the third scenario are presented only for the composting treatment. The one for bio-drying treatment has all the values under $1 \mathrm{OU} / \mathrm{m}^{3}$. 


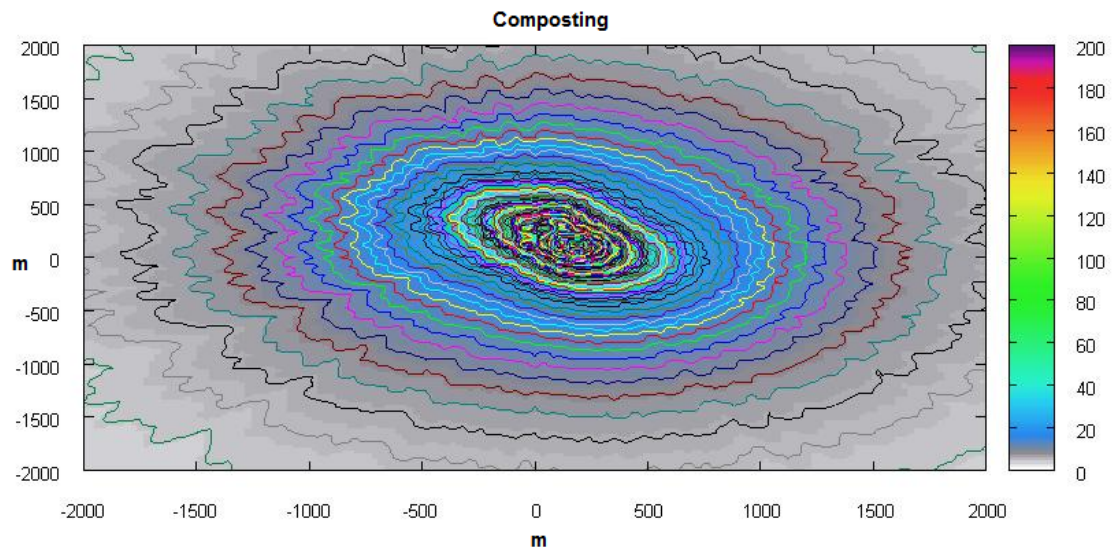

Figure 9: Isoconcentration of maximum hourly values (yearly basis) for composting : RTO at $25 \mathrm{~m}$.

For a better understanding of the impact in the case of composting, in fig. 10 the contribution at different distance $(200 \mathrm{~m}, 500 \mathrm{~m}$ and $1000 \mathrm{~m})$ of each area (reception and biological oxidation, maturation and storing) are presented taking into account for the process air treatment the three proposed scenarios and referring to the most critical direction (west).

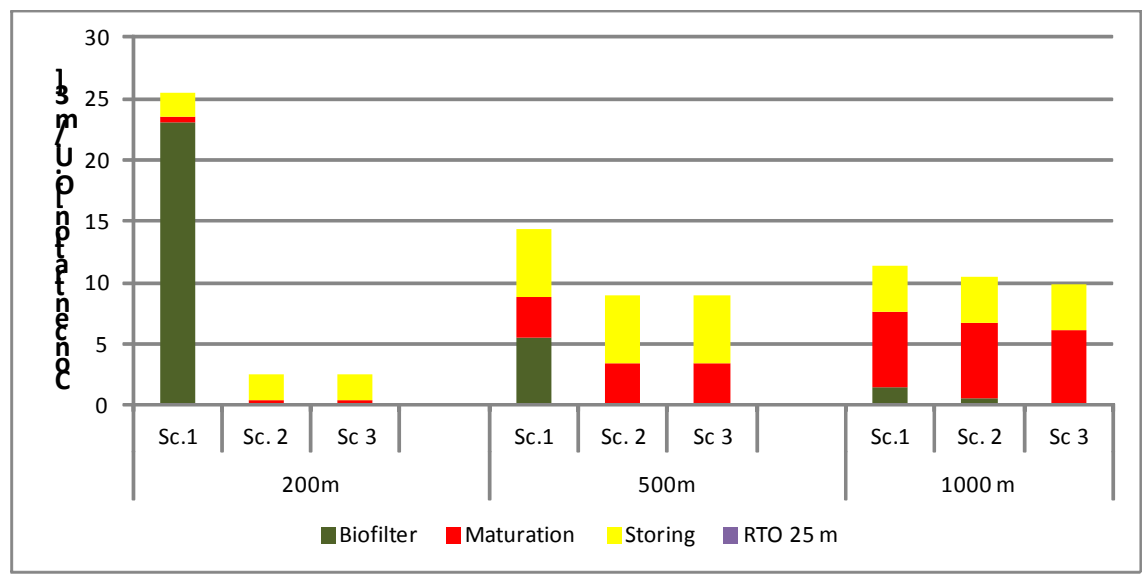

Figure 10: Concentration values for the composting plant.

Taking into account the data presented in fig. 10, it is clear the first scenario with the biofilter at ground level is the most impacting from the odor point of view. The distance has an important role, total concentration decreasing in the first scenario from $25.5 \mathrm{OU} / \mathrm{m}^{3}(200 \mathrm{~m})$, to $14.4 \mathrm{OUm}^{3}(500 \mathrm{~m})$, to $11.4 \mathrm{OU} / \mathrm{m}^{3}$ $(1000 \mathrm{~m})$ respectively. However that means that the impact of the plant is not negligible, being one order of magnitude higher than the values requested in the 
Lombardy regulations for the residential area. The same problems can be found in the case of commercial and agricultural/industrial areas; the influence of maturation and storing areas are visible in all the cases.

The second scenario with the biofilter on the roof is more equilibrated. The impact is reduced but not negligible. Also in this case in the commercial and agricultural/industrial areas the odor concentration are almost double than the one requested by the Lombardy regulation. The reason is the influence of maturation and storing areas that increase with the increase of distance.

The third scenario with RTO system, has an impact similar with the one from the second scenario, maturation and storing being the most impacting areas. The economical effort related to the adoption of RTO results useless because of the presence of non-conveyed odor sources.

Also for the case of bio-drying an overview of the three scenarios is presented. The lowest acceptable distances in the first and second scenarios (biofilter at ground level and on the roof), needed for complying with the regulation, are presented in the table 2 . The impact is not symmetric because of the meteorological characteristics of the site.

Table 2: Distances for complying regulation target when a biofilter is adopted for the bio-drying plant.

\begin{tabular}{|c|c|c|c|c|c|c|}
\hline & $\begin{array}{c}\text { B. at } \\
\text { ground } \\
\text { level }\end{array}$ & $\begin{array}{c}\text { B. on } \\
\text { the } \\
\text { roof }\end{array}$ & $\begin{array}{c}\text { B. at } \\
\text { ground } \\
\text { level }\end{array}$ & $\begin{array}{c}\text { B. on } \\
\text { the } \\
\text { roof }\end{array}$ & $\begin{array}{c}\text { B. at } \\
\text { ground } \\
\text { level }\end{array}$ & $\begin{array}{c}\text { B. on } \\
\text { the roof }\end{array}$ \\
\hline & $5 \mathrm{OU}_{\mathrm{E}} / \mathrm{m}^{3}$ & \multicolumn{2}{|c|}{$3 \mathrm{OU}_{\mathrm{E}} / \mathrm{m}^{3}$} & \multicolumn{2}{|c|}{$1 \mathrm{OU}_{\mathrm{E}} / \mathrm{m}^{3}$} \\
\hline North & $1,008 \mathrm{~m}$ & $432 \mathrm{~m}$ & $1,464 \mathrm{~m}$ & $696 \mathrm{~m}$ & $>1,500 \mathrm{~m}$ & $>1,500 \mathrm{~m}$ \\
\hline South & $984 \mathrm{~m}$ & $192 \mathrm{~m}$ & $1,464 \mathrm{~m}$ & $456 \mathrm{~m}$ & $>1,500 \mathrm{~m}$ & $>1,500 \mathrm{~m}$ \\
\hline West & $912 \mathrm{~m}$ & $264 \mathrm{~m}$ & $1,368 \mathrm{~m}$ & $528 \mathrm{~m}$ & $>1,500 \mathrm{~m}$ & $>1,500 \mathrm{~m}$ \\
\hline East & $1,008 \mathrm{~m}$ & $288 \mathrm{~m}$ & $1,464 \mathrm{~m}$ & $576 \mathrm{~m}$ & $>1,500 \mathrm{~m}$ & $>1,500 \mathrm{~m}$ \\
\hline $\begin{array}{c}\text { North- } \\
\text { East }\end{array}$ & $1,056 \mathrm{~m}$ & $384 \mathrm{~m}$ & $>1,500 \mathrm{~m}$ & $672 \mathrm{~m}$ & $>1,500 \mathrm{~m}$ & $>1,500 \mathrm{~m}$ \\
\hline $\begin{array}{c}\text { South- } \\
\text { East }\end{array}$ & $1,056 \mathrm{~m}$ & $216 \mathrm{~m}$ & $>1,500 \mathrm{~m}$ & $504 \mathrm{~m}$ & $>1,500 \mathrm{~m}$ & $>1,500 \mathrm{~m}$ \\
\hline $\begin{array}{c}\text { South- } \\
\text { West }\end{array}$ & $960 \mathrm{~m}$ & $192 \mathrm{~m}$ & $1,416 \mathrm{~m}$ & $480 \mathrm{~m}$ & $>1,500 \mathrm{~m}$ & $>1,500 \mathrm{~m}$ \\
\hline $\begin{array}{c}\text { North- } \\
\text { West }\end{array}$ & $984 \mathrm{~m}$ & $360 \mathrm{~m}$ & $1,464 \mathrm{~m}$ & $648 \mathrm{~m}$ & $>1,500 \mathrm{~m}$ & $>1,500 \mathrm{~m}$ \\
\hline
\end{tabular}

The case of RTO is not reported as the targets are reached in all the territory. This is an important difference compared to composting.

\section{Conclusions}

The use of the mathematical model AERMOD has given the chance to obtain an overall frame regarding the impact from a composting or a bio-drying plant on the territory where they could be placed. 
Taking into account the obtained results, the most common system for process air treatment in the case of composting plants shows to be the worst in terms of impact on the territory. One of the reasons is the fact that the source area which represents the bio-filter is virtually at ground level and is less affected by the dilution effects. Besides this aspect it was noted that the maturation and storage phases of the final product have a crucial contribution to the total impact.

For the bio-drying case, the optimal solution for minimization of the odor impact resulted with the one with RTO option applied for air treatment. Biofilter costs less but this paper demonstrates that the impact of a plant adopting this option could not comply with the quality targets of modern regulations. The design strategy of placing a bio-filter on the roof of the plant can guarantee a lower impact mainly in the surroundings of the plant. Of course the results are representative of areas with a meteorology similar to the one of the case-study. In Italy flat zones as the studied one are typical, thus this paper is useful for pointing out the necessity of adequate studies and design criteria on each case.

\section{References}

[1] Ragazzi, M., Rada, E.C., Antolini, D. Material and energy recovery in integrated waste management systems: an innovative approach for the characterization of the gaseous emissions from residual MSW bio-drying, Waste Management, 31(9-10), pp. 2085-2091, 2011.

[2] Rada E.C. and Ragazzi M. Municipal Solid Waste bio-drying: odor problem of three configurations, Proc. of the IV International Symposium $M B T$ and $M R F$, pp. 375-386, 2011.

[3] He, P., Tang, J., Zhang, D., Zeng, Y., Shao, L. Release of volatile organic compounds during bio-drying of municipal solid waste, Journal of Environmental Sciences, 22(5), pp. 752-759, 2010.

[4] Sironi, S., Capelli, L., Céntola, P., Del Rosso, R. Il Grande, M. Odour emission factors for the prediction of odour emissions from plants for the mechanical and biological treatment of MSW, Atmospheric Environment, 40(39), pp. 7632-7643, 2006.

[5] Zhang, J., Yu, L.Z., He, P.J., Zhang, H., Shao, L.M. Effect of green wastes mixing on VSCs emission during MSW composting, China Environmental Science, 31(1), pp. 68-72, 2011.

[6] Sironi, S., Capelli, L., Céntola, P., Del Rosso, R. Odour emissions from MSW composting process steps, International Journal of Environmental Technology and Management, 7(3-4), pp. 304-316, 2007.

[7] DGR n.7/12764 "Linee guida relative alla costruzione e all'esercizio degli impianti di produzione di compost" - Guideline for contruction and operation of a composting plant, Italy, 2003.

[8] 30 BImSchV „Dreißigste Verordnung zur Durchführung des BundesImmissionsschutzgesetzes über Anlagen zur biologischen Behandlung von Abfällen" - Decree for the implementation of the Federal Law on Emissions Control from waste biological treatment plants, Germany 2001. 
24 Waste Management and the Environment VI

[9] EPA, User's Guide for the AMS/EPA Regulatory Model AERMOD. EPA454/B-03-001, U.S. Environmental Protection Agency, Research Triangle Park, NC, 2004.

[10] EPA, User's Guide for the AERMOD Meteorological Preprocessor (AERMET), EPA-454/B-03-002. U.S. Environmental Protection Agency, Research Triangle Park, NC, 2004.

[11] Negoi, R.M., Ragazzi, M., Apostol T., Rada, E.C., Marculescu, C. Biodrying of Romanian Municipal Solid Waste: an analysis of its viability, Scientific Bulletin- Politehnica University of Bucharest. Series C, Electrical Engineering, 71(4), pp. 193-204, 2009.

[12] Rada, E.C., Franzinelli, A., Taiss, M., Ragazzi, M., Panaitescu, V., Apostol, T. Lower Heating Value Dynamics during Municipal Solid Waste BioDrying, Environmental Technology, 28 (4), pp. 463-470, 2007. 